\title{
Phenotypic and Molecular Identification of Bacterial Species in Indian Major Carps and Exotic Carps from South 24 Parganas, West Bengal, India
}

\author{
Koel Bhattacharya Sanyal, Debapriyo Mukherjee, \\ Ananya Guchhait and Gadadhar Dash*
}

\author{
Department of Aquatic Animal Health, Faculty of Fishery Sciences, West Bengal University of \\ Animal and Fishery Sciences 5, Budherhat Road, Chakgaria, P.O. Panchsayar, \\ Kolkata, Pin-700094, West Bengal, India
}

\begin{abstract}
A B S T R A C T
The present study was done to find rapid and accurate identification of bacterial species which will help in prevention and cure of diseases in various aquatic animals. Phenotypic identification of bacterial isolates was done by conventional tests and commercial methods. Antibiotic sensitivity study revealed only gatifloxacin and chloramphenicol were found to be effective, both inhibited $83.33 \%$ sensitivity to the bacterial strains. Prevalence study revealed that aeromoniais were the dominant disease. The identities of selected bacterial strains were further confirmed by molecular characterization through $16 \mathrm{~S}$ rDNA analysis. In $1.2 \%$ agarose gel electrophoresis, approximately $1.5 \mathrm{kbp}$ bands were obtained by PCR amplification. In 2\% agarose gel electrophoresis, approximately 675 bp and 1100 bp bands were obtained by PCR amplification for two Flavobacterium columnare specific primers set. Among the 7 isolates, 2 were identified as Commonas aquatica (accession number KT716080) and Aeromonas hydrophila (accession number KX455879) by using universal primers. Three isolates were identified as Flavobacterium columnare using specific primers by culture dependant and culture-independent methods. The sequence results of other bacterial isolates are awaited. The gene sequences of culture independent samples and culture dependent strains Commonas aquatica and Aeromonas hydrophila have been submitted to NCBI with accession numbers KX452118, KX452119, KT716080, KX455879, respectively.
\end{abstract}

Keywords

Antibiotic

sensitivity, Exotic

Carps, Indian Major

Carps, NCBI, PCR

Article Info

Accepted:

06 December 2017

Available Online:

10 January 2018

\section{Introduction}

Carps are the major group of freshwater fish that have a global significance as a source of food and as experimental models for research. Modern fish farming with high stocking densities and intensive production units provide ideal conditions for the invasion and persistence of a range of pathogens (bacteria, viruses, protozoan and metazoan parasites). Infections by these disease-causing agents reduce the condition and survival of fish causing economical losses to farmers. However, treatments unavoidably cause problems related to environmental pollution, drug resistance and health issues, which is environmentally and ecologically sustainable 
solutions are now being sought in fish farming. Reaching this long-term objective will depend on the detailed information and knowledge on the ecology of main disease threats (Karvonen et al., 2005).

The development of aquaculture faces a number of problems, of which diseases particularly the emergence of new pathogens represent serious risk for the production of aquatic animals and also for the health of fish farmers and of the consumers of aquaculture products. Carps being the mostly cultured fish species in West Bengal and infectious diseases of cultured freshwater carps are one of the major problems to successful aquaculture, which cause economic losses in aquaculture industry. To study fish diseases, it is important to acquire knowledge on different pathogens, their biology and life cycle. Cultured carps are susceptible to various kinds of diseases, viz., bacterial, fungal, viral, parasitic, environmental and nutritional.

The most common bacteria isolated from carp culture systems are Aeromonas sp. and Pseudomonas sp. and Enterobactericeae. Among Aeromonas sp., the most common species are Aeromonas hydrophila, A. sobria and A. caviae. Other authors (Rehulka, 2002; Taylor, 2003) have depicted A. hydrophila and A. sobria as causative agents of motile aeromonas septicemia (MAS) in fish and other aquatic animals. Gopalakrishnan (1961) recorded epizootics of infectious dropsy due to Aeromonas hydrophila in the three major types of Indian major carps in fish stocking tanks in West Bengal. Ulcerative forms of infection in Catla catla (Hamilton) and septicemia in three species of carp were recorded by others (Karunasagar et al., 1986; Karunasagar et al., 1989). Since, carps are the most important freshwater species cultured in West Bengal and proper fish disease monitoring is still lacking as suitable surveillance system is far from reality, so, protection of these fish against diseases is vital to the aquaculture industry.

Therefore, the present study was undertaken to investigate the phenotypic and molecular identification of emerging fish pathogen (bacteria) in Indian Major Carps and Exotic carps from South 24 Parganas district, West Bengal.

\section{Materials and Methods}

\section{Sampling area}

The present study on the surveillance of diseases in Indian major and exotic carps was carried out for a period of 12 months from January 2016 to December 2016. The diseased fish samples were collected from different fish farms located in different areas of South 24 Parganas district of West Bengal, viz., Chakgaria, Haripota, Katipota, Sonarpur, Bonhooghly, Canning II, Uttardanga, Bamanghata, Bhangar, Gangasagar.

\section{Experimental fish}

The experimental fish for the present study include three species of Indian major and exotic carps, viz., Labeo rohita, Catla catla, Cirrhinus mrigala and Hypophthalmichthys molitrix, Ctenopharyngodon idella, Cyprinus carpio cultured in semi-intensive and intensive farms of the above mentioned areas.

\section{Sampling}

On each sampling day, a minimum of 60 Indian major and exotic carps were examined for diseases as per OIE guidelines (2013). Information on behavioural abnormalities, gross and clinical signs was recorded on the sampling sheet. Carps with typical disease symptoms were sampled for different experiments.

\section{Bacteriological analyses}


At the laboratory, inocula from each transport media or from the lesions or affected external and internal parts such as gills, intestine, cutaneous lesions and kidney of morbid fish were streaked on to GSPA, RSA, CA, SA and TSA/BHIA plates and incubated at $30 \pm 2{ }^{\circ} \mathrm{C}$ for 24-48 h.

\section{Bacterial isolation and phenotypic characterization}

Based on the dominance and definite colony morphology, representative colonies were picked from each plate and purified by repeated streaking on TSA and maintained on TSA slants.

A series of biochemical reactions as described by others (Lechevallier et al., 1980; Collins et al., 2004) were performed to identify bacteria up to genus level.

Taxonomic keys proposed by University of Idaho, USA as per Bergey's Manual of Determinative Bacteriology 9th Edition (Holt et al., 1994) were also consulted for the identification bacterial species.

Taxonomic keys proposed by Arcos et al.,'1988 (Arcos et al., 1988) and the current literatures on Aeromonas spp. were followed for Aeromonas identification (Minana-Galbis et al., 2009; Alperi et al., 2010; Figueras et al., 2011; Austin et al., 2012; Soto-Rodriguez et al., 2013; Chen et al., 2016; Shewan et al., 1960), Bergey's manual (Collins et al., 2004; Holt et al., 1994) were consulted for Pseudomonas identification.

Identification of selected bacterial isolates on the basis of biochemical characterization was done by an automated bacterial identification system (VITEK 2 - compact, BioMerieux, France).

Molecular characterization
Bacterial DNA extraction and PCR amplification of $16 \mathrm{~S}$ rDNA gene

Genotypic characterization of select bacterial isolates was done by $16 \mathrm{~S}$ rDNA sequencing. The genomic DNA of bacterial isolates were extracted by using genomic DNA isolation kit (Macherey-Nagel, Germany) as per the manufacturer's protocol. The $16 \mathrm{~S}$ rDNA gene was amplified through PCR reaction that was performed in a Master cycler Pro S system (Eppendorf, Germany). The universal primers (forward primer $8 \mathrm{~F}$ and reverse primer 1492R) of amplification size $1400 \mathrm{bp}$ were used.

The species specific primers (forward primer Col-72F and reverse primer Col-1260R) of amplification size 800-1000 bp were used. Another set of species specific primers (forward primer ColF and reverse primer ColR) of amplification size $675 \mathrm{bp}$ were also used.

\section{Agarose gel electrophoresis}

The PCR products were analysed on $1.2 \%$ and $2 \%$ agarose (HiMedia, India) gels containing $0.5 \mu \mathrm{g} / \mathrm{ml}$ ethidium bromide in $1 \mathrm{X}$ Trisacetate- EDTA (TAE) buffer.

\section{DNA sequencing and analysis}

Seven bacterial isolates were randomly selected for further characterization and identified through $16 \mathrm{~S}$ rDNA analysis. This assay involved DNA isolation, amplification and sequencing of the gene coding for $16 \mathrm{~S}$ rDNA, i.e., the $1.5 \mathrm{kbp} 16 \mathrm{~S}$ rDNA from bacterium and $675 \mathrm{bp}$ and $1100 \mathrm{bp}$ specific for Flavobacterium columnare bacterium.

The PCR amplified products were sequenced at the Genomics Division, Xcelris Labs Ltd, Ahmedabad, India.

Antibiogram 
A total of 42 bacterial strains were screened for their sensitivity to 12 potential antibiotics by agar disc diffusion technique (Bauer et al., 1966; CLSI, 2006) on MHA plates.

\section{Statistical analysis}

One-way analysis of variance (ANOVA) using Microsoft excel version 2007 was applied to test the significance of difference in antibiotic sensitivity assay among the antibiotic agents, bacterial species and fish species (Kholil et al., 2015).

\section{Results and Discussion}

The phenotypic characteristics of selected Gram negative bacteria and Gram positive bacterial strains from diseased Indian major and exotic carps as determined by an automated bacterial identification system (VITEK 2 Compact, Biomerieux, France) and also conventional biochemical tests. The detailed information on the bacterial strains used, host species, site of infection, bionumbers with identified bacterial strains are listed in Table 1.

The selected bacterial strains were identified by automated bacterial identification system (VITEK 2 Compact, Biomerieux, France) as Pseudomonas stutzeri, Citrobacter freundii, Aeromonas hydrophila, Pseudomonas aeruginosa, Acinetobacter baumannii complex, Pseudomonas fluorescens/ mendocina, Aeromonas sobria, Pseudomonas putida, Yersinia enterocolitica/frederikesenii, Klebsiella pneumoniae sp. pneumoniae, Enterobacter cloacae complex, Acinetobacter radioresistens and Kocuria rhizophila. The Gram negative bacterial strains were identified through biochemical test as Aeromonas schuberti, Aeromonas sobria, Aeromonas veronii biovar veronii, Aeromanas popoffii,
Aeromonas fluvialis, Aeromonas jandaei, Aeromonas hydrophila sub sp. ranae, Aeromonas tecta, Aeromonas aquariorum, Aeromonas caviae, Aeromonas eucrenophila, Aeromonas bestiarum, Aeromonas veronii biovar sobria, Aeromonas hydrophila, Enterobacteriaceae, Pseudomonas sp. and Flavobacterium sp.

\section{Molecular characterization}

\section{$16 S$ rDNA gene analysis}

Randomly selected 7 bacterial strains were further characterized and identified through $16 \mathrm{~S}$ rDNA analysis. The detailed information on the bacterial strains used, host species, clinical signs, site of infection, NCBI GenBank accession numbers are listed in Table 2. In $1.2 \%$ agarose gel electrophoresis, approximately $1.5 \mathrm{kbp}$ bands were obtained with $16 \mathrm{~S}$ universal primers for bacterial isolates and in $2 \%$ agarose gel electrophoresis, approximately $675 \mathrm{bp}$ and $1100 \mathrm{bp}$ bands were obtained by PCR amplification for $F$. columnare bacterial isolates for two $F$. columnare specific primers having different amplification size by PCR amplification (Fig. 1, 2 and 3). Among the 7 isolates, 2 were identified as Commonas aquatica (BUBKT, accession number KT716080) and Aeromonas hydrophila (BTRCTR, accession number KX455879) by using universal primers. Three isolates were identified as Flavobacterium columnare using $F$. columnare specific primers by culture dependant and cultureindependent methods. The sequence results of other bacterial isolates are awaited. The gene sequences of culture independent samples (RG1 and C1) and culture dependent strains Commonas aquatica BUBKT and Aeromonas hydrophila BTRCTR have been submitted to NCBI with accession numbers KX452118, KX452119, KT716080, KX455879, respectively. 


\section{Primers}

\begin{tabular}{|c|c|c|c|c|}
\hline \multicolumn{2}{|c|}{ Primers } & Sequence (5'-3') & & Reference \\
\hline \multirow{2}{*}{$\begin{array}{l}\text { Universal primers } \\
\text { for bacterial } \\
\text { isolates }\end{array}$} & $8 \mathrm{~F}$ & CTGGCTCAG & \multirow[t]{2}{*}{$1400 \mathrm{bp}$} & \multirow{2}{*}{$\begin{array}{l}\text { Eden et al., } \\
\quad 1991\end{array}$} \\
\hline & 149 & $\begin{array}{r}\text { TACGGYTACCTTGTTACGAC } \\
\text { TT }\end{array}$ & & \\
\hline \multirow{4}{*}{$\begin{array}{l}\text { Flavobacterium } \\
\text { columnare } \\
\text { specific primers }\end{array}$} & Col-72 & GAAGGAGCTT-GTTCCTTT & \multirow{2}{*}{$\begin{array}{c}800-1000 \\
\text { bp }\end{array}$} & \multirow{2}{*}{$\begin{array}{l}\text { Triyanto et } \\
\text { al., } 1999\end{array}$} \\
\hline & Col-1260R & GCCTACTTGCGT-AGTG & & \\
\hline & ColF & CAGTGGTGAAATCTGGT & \multirow[t]{2}{*}{$675 \mathrm{bp}$} & \multirow{2}{*}{$\begin{array}{l}\text { Darwish et } \\
\text { al., } 2004\end{array}$} \\
\hline & ColR & GCTCCTACTTGCGTAGT & & \\
\hline
\end{tabular}

Table.1 Identification of bacterial strains from diseased Indian major and exotic carps by Vitek 2 Compact System

\begin{tabular}{|c|c|c|c|c|}
\hline Fish species & $\begin{array}{l}\text { Site of } \\
\text { infection }\end{array}$ & Strain & Bionumber & Identification \\
\hline Labeo rohita & Kidney & R3SK-1 & 0003041203500000 & Pseudomonas aeruginosa \\
\hline Labeo rohita & Kidney & RGP-1 & 0201010103500302 & Acinetobacter baumannii complex \\
\hline Catla catla & Gill & CGP-1 & 0001010103500342 & Acinetobacter baumannii complex \\
\hline Catla catla & Gill & $\mathrm{CBC}-1$ & 0001001103501252 & $\begin{array}{l}\text { Pseudomonas } \\
\text { fluorescens/mendocina }\end{array}$ \\
\hline Catla catla & Kidney & CG1-1 & 1425611151400271 & Aeromonas sobria \\
\hline Catla catla & Kidney & CRG-1 & 0003051101500352 & Pseudomonas putida \\
\hline Labeo rohita & Kidney & R3BK1-1 & 4231710450000210 & $\begin{array}{l}\text { Yersinia } \\
\text { enterocolitica/frederiksenii }\end{array}$ \\
\hline Labeo rohita & Kidney & R3BK2-1 & 6607735553561050 & $\begin{array}{l}\text { Klebsiella pneumoniae ssp. } \\
\text { Pneumonia }\end{array}$ \\
\hline Labeo rohita & Kidney & R2RGg-1 & 0001011101500352 & Acinetobacter baumannii complex \\
\hline Labeo rohita & Kidney & R2RGLg-1 & 0627634553532010 & Enterobacter cloacae complex \\
\hline Cirrhinus mrigala & Gill & MGG & 001000000100202 & Unidentified organism \\
\hline Cirrhinus mrigala & Kidney & $\mathrm{MBK}$ & 1465615151400271 & Aeromonas sobria \\
\hline Cirrhinus mrigala & Surface & $\mathrm{MBH}$ & 010010302000000 & Kocuria rhizophila \\
\hline Cirrhinus mrigala & Gill & MBG & 0000000102100000 & Acinetobacter radioresistens \\
\hline Cyprinus carpio & Kidney & CRK1.1 & 0000000102100000 & Acinetobacter radioresistens \\
\hline Cyprinus carpio & Kidney & CGK1 & 0041000000100202 & Unidentified organism \\
\hline Labeo rohita & Gill & R2BKc-1 & 0005201102500000 & Pseudomonas stutzeri \\
\hline Labeo rohita & Gill & R2GKp-1 & 0005201102500000 & Pseudomonas stutzeri \\
\hline Labeo rohita & Kidney & R3RKb-1 & 4617611747441210 & Citrobacter freundii \\
\hline $\begin{array}{l}\text { Hypophthalmichthys } \\
\text { molitrix }\end{array}$ & Gill & SRG-1 & 1465611351500271 & Aeromonas sobria \\
\hline Labeo rohita & Kidney & R2TK-1 & 1625703150540231 & Aeromonas hydrophila \\
\hline Labeo rohita & Kidney & R3SK1 & 423170551000210 & Unidentified organism \\
\hline
\end{tabular}


Table.2 Molecular characterization of bacterial and parasitic strains isolated from diseased Indian major and exotic carps

\begin{tabular}{|c|c|c|c|c|c|c|}
\hline Fish species & $\begin{array}{c}\text { Disease/ } \\
\text { Clinical sign }\end{array}$ & $\begin{array}{c}\text { Site of } \\
\text { infection }\end{array}$ & $\begin{array}{l}\text { Strain } \\
\text { code }\end{array}$ & $\begin{array}{l}\text { Length } \\
\text { (bp) }\end{array}$ & $\begin{array}{c}\text { Gene Bank } \\
\text { Accession } \\
\text { number }\end{array}$ & $\begin{array}{l}\text { Identification of } \\
\text { Bacterial strains }\end{array}$ \\
\hline $\begin{array}{l}\text { Labeo } \\
\text { rohita }\end{array}$ & Tail and fin rot & Fin & BUBKT & 1332 & KT716080 & $\begin{array}{l}\text { Comamonas } \\
\text { aquatica }\end{array}$ \\
\hline Catla catla & Deep ulceration & Kidney & $\begin{array}{l}\text { BTRCT } \\
\mathrm{R}\end{array}$ & - & KX455879 & $\begin{array}{l}\text { Aeromonas } \\
\text { hydrophila }\end{array}$ \\
\hline $\begin{array}{l}\text { Labeo } \\
\text { rohita }\end{array}$ & $\begin{array}{l}\text { Body } \\
\text { haemorrhage }\end{array}$ & Kidney & R3BK1 & - & - & Results awaited \\
\hline $\begin{array}{l}\text { Labeo } \\
\text { rohita }\end{array}$ & Haemorrhage & Kidney & $\mathrm{R} 3 \mathrm{RKb}$ & - & - & Results awaited \\
\hline $\begin{array}{l}\text { Labeo } \\
\text { rohita }\end{array}$ & $\begin{array}{ll}\text { Focal } & \text { gill } \\
\text { necrosis }\end{array}$ & Gill & R3GS & - & $\begin{array}{l}\text { Submitted to } \\
\text { NCBI }\end{array}$ & $\begin{array}{l}\text { Flavobacterium } \\
\text { columnare }\end{array}$ \\
\hline $\begin{array}{l}\text { Labeo } \\
\text { rohita }\end{array}$ & $\begin{array}{l}\text { Gill rot and } \\
\text { focal necrosis }\end{array}$ & Gill & RG1 & - & KX452118 & $\begin{array}{l}\text { Flavobacterium } \\
\text { columnare }\end{array}$ \\
\hline $\begin{array}{l}\text { Ctenophary } \\
\text { ngodon } \\
\text { idella }\end{array}$ & Saddle back & $\begin{array}{l}\text { Dorsal } \\
\text { region }\end{array}$ & $\mathrm{C} 1$ & - & KX452119 & $\begin{array}{l}\text { Flavobacterium } \\
\text { columnare }\end{array}$ \\
\hline
\end{tabular}

Table.3 ANOVA for antibiotics with respect to bacterial flora

\begin{tabular}{|l|l|l|l|l|l|l|}
\hline Source of Variation & SS & $d f$ & MS & F & P-value & F crit \\
\hline Between Groups & 122292.7 & 24 & 5095.529 & 2.620773 & $\begin{array}{l}9.26 \mathrm{E}- \\
05\end{array}$ & 1.557046 \\
\hline Within Groups & 534678.2 & 275 & 1944.284 & & & \\
\hline & & & & & & \\
\hline Total & 656970.9 & 299 & & & & \\
\hline
\end{tabular}

Table.4 ANOVA for antibiotics with respect to fish species

\begin{tabular}{|l|l|l|l|l|l|l|}
\hline Source of Variation & SS & df & MS & F & P-value & F crit \\
\hline Between Groups & 4136.963 & 4 & 1034.241 & 0.923144 & 0.457215 & 2.539689 \\
\hline Within Groups & 61619.01 & 55 & 1120.346 & & & \\
\hline Total & 65755.97 & 59 & & & & \\
\hline
\end{tabular}


Fig.1 Agarose gel (1.2\%) showing 16S rDNA gene amplicons of bacterial strains of diseased Indian major and exotic carps. M- $1 \mathrm{~Kb}$ molecular weight DNA marker; 1.Comamonas aquatica (BUBKT), 2. Aeromonas hydrophila (BTRCTR), 3. Citrobacter freundii (R3BK1), 4. Yersinia enterocolitica/ frederikesenii (R3RKb)

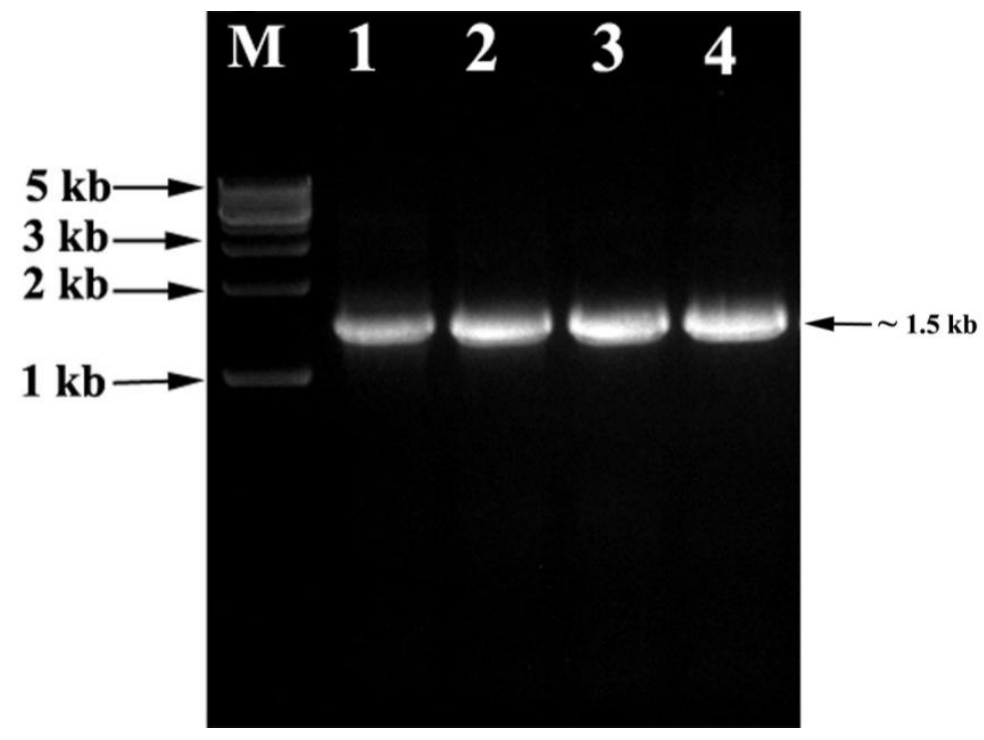

Fig.2 Agarose gel (2\%) showing Flavobacterium columnare specific $16 \mathrm{~S}$ rDNA gene mplicons. $\mathrm{M}-100 \mathrm{bp}$ molecular weight DNA marker; 1. Flavobacterium columnare (R3GS, culture dependent), 2. Flavobacterium columnare (RG1, culture independent), 3.

Flavobacterium columnare

( $\mathrm{C} 1$, culture independent)

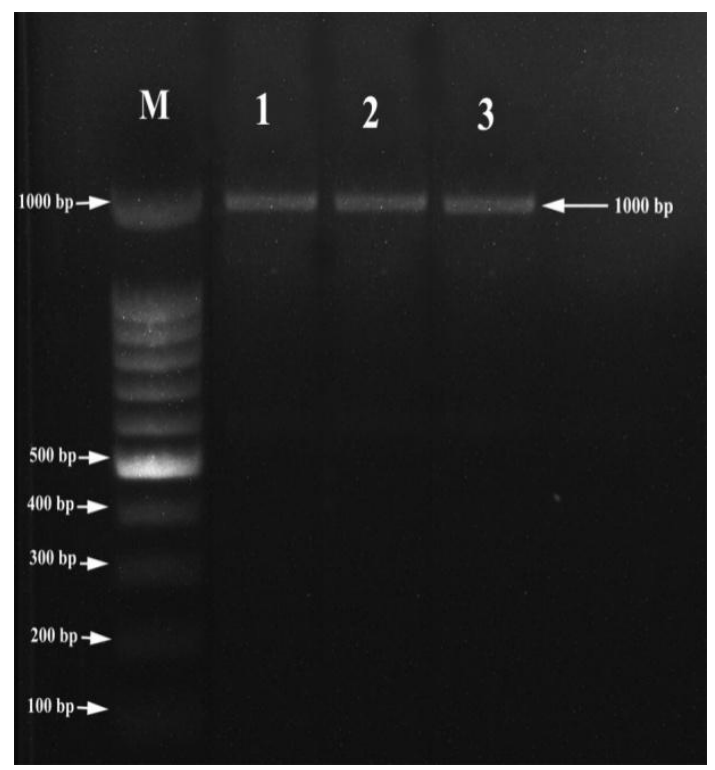

Fig.3 Agarose gel (2\%) showing Flavobacterium columnare specific 16S rDNA gene amplicons ${ }^{*} \mathrm{M}-100 \mathrm{bp}$ molecular weight DNA marker; 1. Flavobacterium columnare (R3GS, culture dependent), 2. Flavobacterium columnare (RG1, culture independent), 3. Flavobacterium columnare $(\mathrm{C} 1$, culture independent)

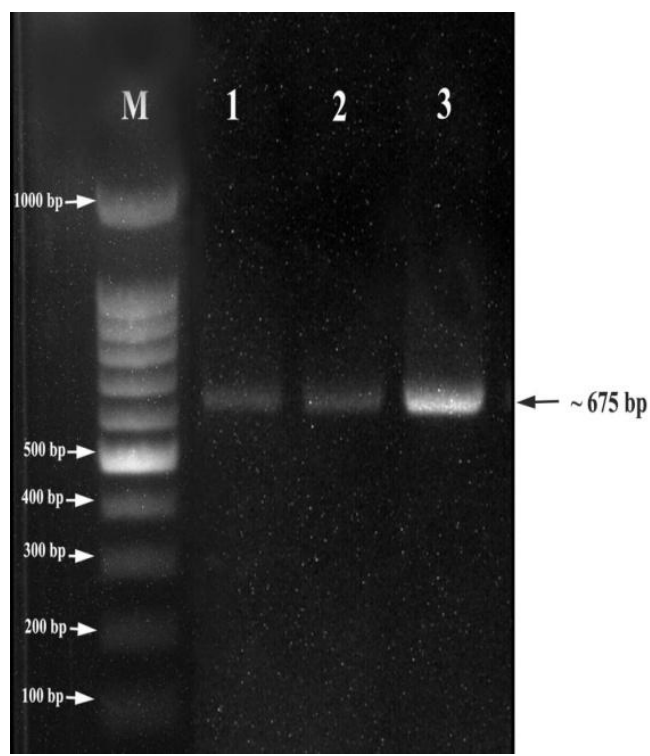


Fig.4 Prevalence of bacterial diseases in Indian major and exotic carps of South 24 Parganas district, West Bengal from January 2016 to December 2016

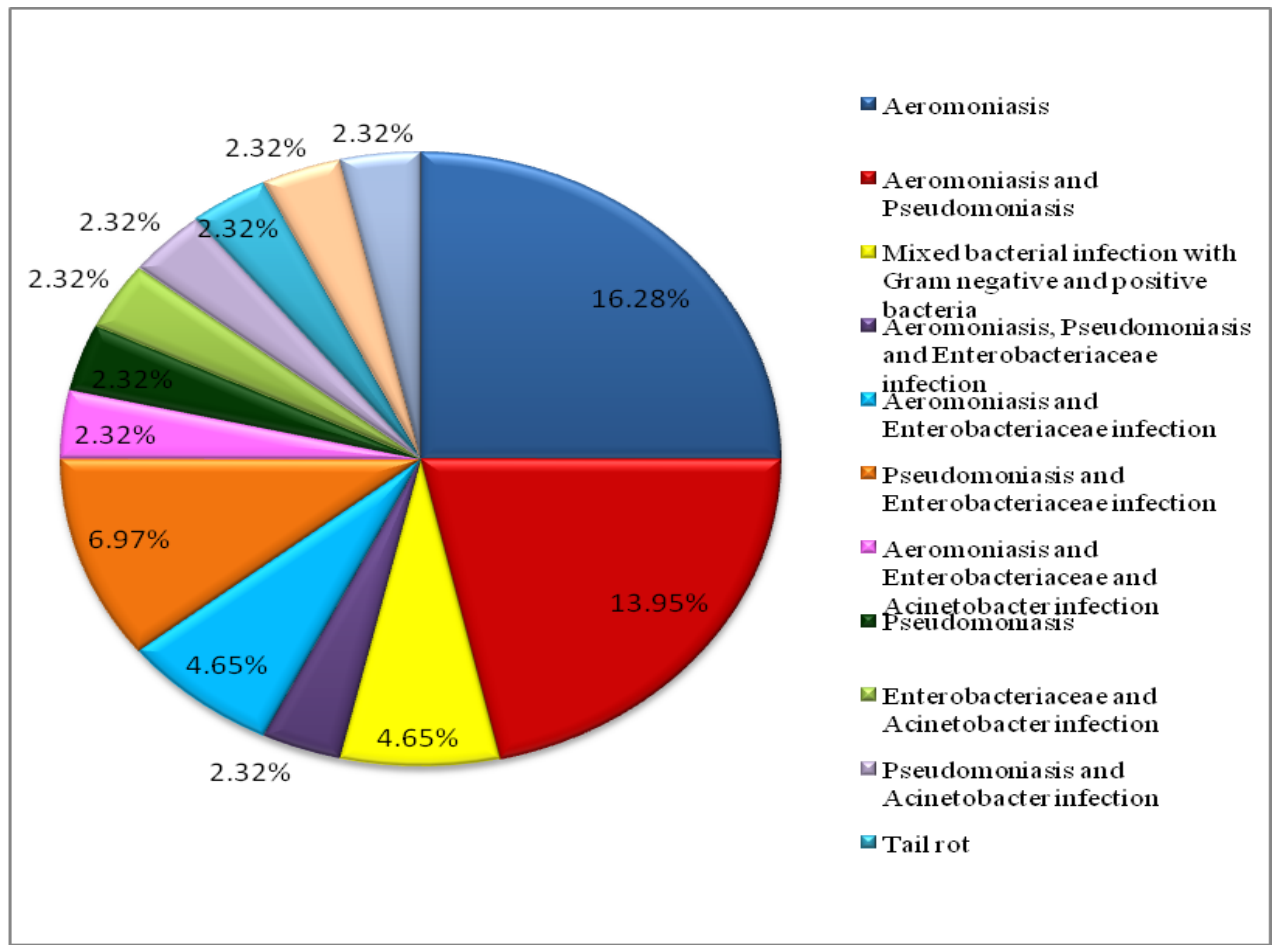

Fig.5 Antibiotic sensitivity $(\%)$ of bacterial flora $(n=42)$ associated with diseased Indian major and exotic carps

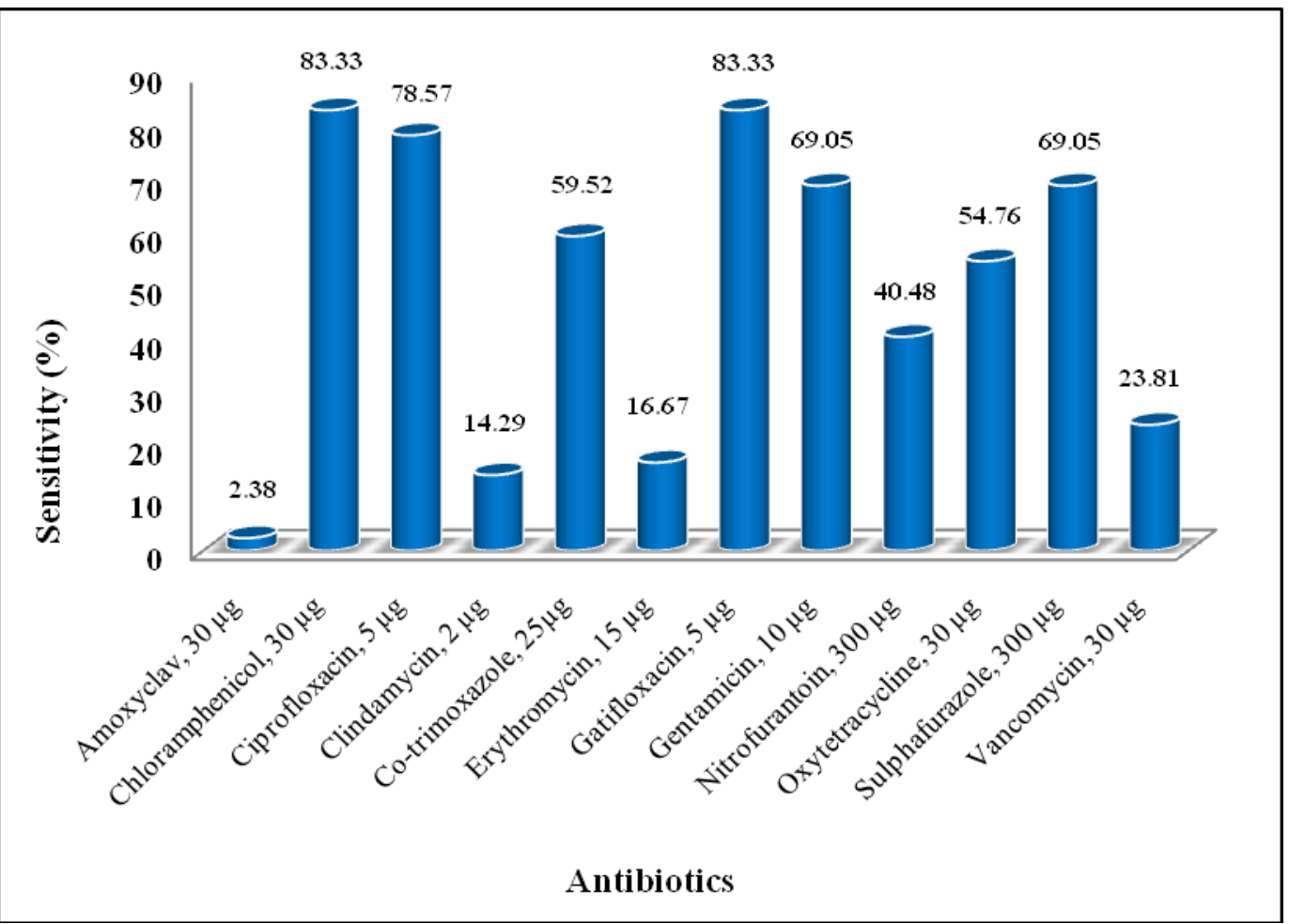




\section{Prevalence of diseases}

The prevalence of bacterial diseases in Indian major and exotic carps in South 24 Parganas district, West Bengal is presented in Fig. 4. Aeromoniasis (16.28\%) were the dominant disease among the bacterial diseases in the district, followed by aeromoniasis and pseudomoniasis $(13.95 \%)$. Pseudomoniasis and Enterobacteriaceae infection (6.97\%) were also common in the district. Mixed bacterial infection with Gram positive and negative bacteria and Aeromoniasis and Enterobacteriaceae infection were also observed with $4.65 \%$ prevalence.

\section{Antibiotic sensitivity testing by agar-disc diffusion assay}

A total of 42 bacterial strains from diseased Indian major and exotic carps were subjected to antibiogram against 12 antibiotics and the results are depicted in Fig. 5. About 83.33\% of the bacterial flora of diseased Indian major and exotic carps from South 24 Parganas district, West Bengal were sensitive to chloramphenicol and gatifloxacin followed by ciprofloxacin $(78.57 \%)$, gentamycin and sulphafurazole $(69.05 \%)$, co-trimoxazole (59.52\%), oxytetracycline (54.76\%), nitrofurantoin $\quad(40.48 \%), \quad$ vancomycin (23.8\%), erythromycin (16.67\%), clindamycin (14.29\%), amoxyclav $(2.38 \%)$.

\section{Statistical analysis}

Statistical analysis revealed that there was a significant difference among the 12 antibiotics $(\mathrm{F}=2.62, \mathrm{P}<0.05)$ with respect to the bacterial flora (Table 3). Statistical analysis also revealed that there was no significant difference among the 12 antibiotics $(\mathrm{F}=0.92, \mathrm{P}<0.05)$ with respect to the fish species (Table 4). Bacterial diseases are responsible for heavy mortality in both wild and cultured freshwater fish. The actual role of these microorganisms may vary from that of a primary pathogen to that of an opportunist invader of a host rendered moribund by some other disease process (Richards et al., 1978). The bad water quality, high organic load, contaminated feed and unhygienic conditions are some of predisposing factors for an outbreak of bacterial diseases in aquatic animals (Mastan, 2013). The aquaculture operation in most of the surveyed areas in the district was under sewage-fed aquaculture, increased conflicts of water for multipurpose use might have favoured the growth of these autochthonous bacteria and subsequently the onset of diseases. The other reasons might be mainly initiated due to environmental stress factors such as high water temperatures, $\mathrm{pH}$ disturbances and low dissolved oxygen levels, overcrowding, heavy parasite infestation, high organic loads in the water, spawning activity, rough handling and transport also may lead to outbreaks of disease. Serious episodes of stress such as oxygen depletion or cases of brown blood disease, caused by nitrite toxicity, often are followed by outbreaks of bacterial infection within a week (Kumar et al., 2013; Jagoda et al., 2014).

In the present study, among all the observed bacterial diseases, aeromoniasis alone was found to be the most dominant disease, occurring throughout the year in Indian major and exotic carps such as H. molitrix, Labeo rohita, Catla catla, Cyprinus carpio. Among all the six fish species screened, $H$. molitrix was most susceptible to aeromoniasis. Likewise, aeromonads infection in H. molitrix had been reported earlier (Sabur, 2006; Sarkar et al., 2012; Rashid et al., 2014; Ali et al., 2014). Aeromonas infection accounted for $45.45 \%$ of diseases of exotic carps, followed by $6.25 \%$ of Indian major carps. Likewise, Aeromonas spp. were earlier reported in exotic carps, H. molitrix by Rashid et al., (2014), in Cyprinus carpio by Yi et al., 
(2012), in Ctenopharyngodon idella by Zheng et al., (2012). Motile Aeromonas species are widely distributed in aquatic environments (Beaz-Hidalgo et al., 2013) and are isolated from water, healthy or diseased fish, food products, animal and human faeces and other clinical and environmental samples. When water quality fails, the fish suffer stress, thus making them more susceptible to infections by opportunistic pathogens such as Aeromonas sp. (Karvonen et al., 2010; Tam et al., 2011). The increased incidence of aeromoniasis in diseased Indian major and exotic carps population is an indication that it is emerging as a major pathogens with the intensification in carp culture system.

Besides aeromoniasis, aeromoniasis and pseudomoniasis $(13.95 \%)$ was the dominant one, occurring throughout the year in diseased Indian major and exotic carps. Motile aeromonads and Pseudomonas sp. were documented in the cultured ponds of Cirrhinus mrigala in Bangladesh (Iqbal, 1995). Likewise, Darak and Barde (2014) reported Aeromonas spp. and Pseudomonas spp. as very common bacteria associated with major carps and live fish. Mixed bacterial infection with Gram positive and negative bacteria was accounted for a total of $4.65 \%$ disease incidence in diseased Indian major and exotic carps such as Labeo rohita and Cirhhinus mrigala. The associated bacterial flora identified were Comamonas aquatica, Aeromonas veronii biovar veronii, Pseudomonas sp. from Labeo rohita and Aeromonas sobria, Acinetobacter radioresistens, Kocuria rhizophila, Pseudomonas sp., Aeromonas tecta, Aeromonas jandaei from Cirhhinus mrigala. Likewise, other (Darak et al., 2014) reported mixed bacterial infection in carps with the association of bacterial flora like Aeromonas sp., Flavobacterium sp., Proteus sp., Staphylococcus sp., Enterobacterium sp., E. coli, Pseudomonas sp. and Vibrio sp.
The antibiotic sensitivity test was done to understand the effectiveness of different antibiotics on 42 bacterial strains from diseased Indian major and exotic carps. Among the 42 bacterial strains tested, 25 strains were of the members of genus Aeromonas, which showed varying degrees of antibiotic resistance. All the species of Aeromonas were resistant to amoxyclav, except two strains of Aeromonas veronnii biovar veronnii. All the 25 strains of Aeromonas spp. were sensitive to chloramphenicol. In the present study, $96 \%$ of the Aeromonas spp. were sensitive to ciprofloxacin except, Aeromonas diversa, which, to some extent, corroborate the results of other (Hatha et al., 2005). They reported that $63 \%$ of the 90 motile aeromonas strains isolated from freshwater fish were sensitive to ciprofloxacin. A wide range of antimicrobial compounds (oxytetracycline, ciprofloxacin, nitrofurantoin, furazolidone or chloramphenicol) are being used in the hatcheries and farms in India to control the bacterial population (Abraham et al., 1997).

The present study was done to find rapid and accurate identification of bacterial species which will help in prevention and cure of diseases in various aquatic animals. The identities of selected bacterial strains were further confirmed by molecular characterization through 16S rDNA analysis (Fig. 1, 2 and 3). These days modern epidemiologists have been using a variety of tools which provide good molecular differentiation and which can be tailored to fit the needs of the both laboratory and clinical study.

The results of the present study can be concluded with a considerable population of Indian major and exotic carp species cultured in West Bengal are susceptible to diseases. Among the various diseases, bacterial diseases have been responsible for significant 
economic problem. Aeromoniasis alone or with other infections were observed to be most dominant disease of Indian major and exotic carp species and evolved as major threat to freshwater aquaculture of West Bengal. Other bacterial pathogens such as Pseudomonas spp., Enterobacteriaceae group, Acinetobacter group, Flavobacterium columnare and Gram positive bacterium were also found to be associated with diseased Indian major and exotic carp but with lesser extent. Phenotypic identification of bacterial isolates were done by conventional tests and commercial methods (VITEK 2 Compact system (Biomerieux, France) and further 7 isolates were selected for genotypic identification, which was done by $16 \mathrm{~S}$ rDNA method. 5 isolates were identified as Comamonas aquatica $(\mathrm{n}=1)$, Aeromonas hydrophila $(\mathrm{n}=1)$ and Flavobacterium columnare $(\mathrm{n}=3)$. Results of other two are still awaited. Antibiotic sensitivity study revealed only gatifloxacin and chloramphenicol were found to be effective, both inhibited $83.33 \%$ sensitivity to the bacterial strains.

Further concern is the increasing incidence of multiple antibiotic resistance. Thus, the results of the present study provide a foundation upon which we can understand the role of these opportunistic pathogens of diseases and their management in aquaculture systems South 24 Parganas district, West Bengal.

\section{Acknowledgements}

The authors gratefully acknowledge the assistance extended by the Faculty of Fishery Sciences, West Bengal University of Animal and Fishery Sciences, West Bengal, India for providing necessary facilities for undertaking the work. Special thanks to National Bureau of Fish Genetic Resources (NBFGR), Lucknow, Uttar Pradesh, India and National Fisheries Development Board (NFDB),
Hyderabad, Telangana, India for financial support during the study.

\section{References}

Abraham, T. J., Manley, R., Palaniappan, R. and Devendran, K 1997. Pathogenicity and antibiotic sensitivity of luminous Vibrio harveyi isolated from diseased penaeid shrimp. Journal of Aquaculture in the Tropics. 12(1): 1-8.

Ali, M. F., Rashid, M., Rahman, M. M. and Haque, M. N. 2014. Pathogenicity of Aeromonas hydrophila in Silver Carp Hypophthalmichthys molitrix and its Control Trial. IOSR Journal of Agricultural and Veterinary Sciences. 7: 2319-2372.

Alperi, A., Martinez-Murcia, A. J., Monera, A., Saavedra, M. J. and Figueras, M. J. 2010. Aeromonas fluvialis sp. nov., isolated from Spanish river. International Journal of Systematic and Evolutionary Microbiology. 60: 72-77.

Arcos, M. L., Vicente, A., Morinigo, M. A., Romero, P. and Borrego, J. J. 1988. Evaluation of several selective media for recovery of Aeromonas hydrophila from polluted waters. Applied and Environmental Microbiology. 54(4): 2786-2792.

Austin, B. and Austin, D. A. 2012. In: Bacterial fish pathogens: Disease of farmed and wild fish, 5th edn., Springer-Praxis in Aquaculture in Fisheries, Praxis Publication Ltd., Chichester, UK.

Bauer, A. W., Kirby, W. M. M., Sherris, J. C. and Turck, M. 1966. Antibiotic susceptibility testing by a standardized single disc method. American Journal of Clinical Pathology. 45(4): 493-496.

Beaz-Hidalgo, R., Martinez-Murcia, A. and Figueras, M. J. 2013. Reclassification of Aeromonas hydrophila sub sp. dhakensis and Aeromonas aquariorum 
and emendation of the species Aeromonas hydrophila. Systemic and Applied Microbiology. 36: 171-176.

Chen, P. L., Lamy, B. and Ko, W. C. 2016. Aeromonas dhakensis, an increasingly recognized human pathogen. Frontiers in Microbiology. 7: 793.

CLSI 2006. Clinical and laboratory standards institute. Document M42-A, Methods for Antimicrobial Disk Susceptibility Testing of Bacteria Isolated from Aquatic Animals; Approved Guideline CLSI, 940 West Valley Road, Suite 1400, Wayne, Pennsylvania, USA, pp 19087-1898.

Collins, C. H., Lyne, P. M., Grange, J. M. and Falkinham, J. O. 2004. In: Microbiological Methods, $8^{\text {th }}$ edn., Arnold, a member of the Hodder Headline Group, 338 Euston Road, London.

Darak, O. and Barde, R. D. 2014. Association of Bacterial pathogens with Labeo Rohita in Marathwada region of Maharashtra. International Journal of Advanced Biotechnology and Research. 5(4): 777-783.

Darwish, A. M., Ismaiel, A. A., Newton, J. C. and Tang, J. 2004. Identification of Flavobacterium columnare by a species-specific polymerase chain reaction and renaming of ATCC43622 strain to Flavobacterium johnsoniae. Molecular and Cellular Probes. 18: 421-427.

Eden, P. A., Schmidt, T. M., Blakemore, R. P. and Pace, N. R. 1991. Phylogenetic analysis of Aquaspirillum magnetotacticum using polymerase chain reaction-amplified 16SrRNAspecific DNA. International Journal of Systematic Bacteriology. 41(2): 324325.

Figueras, M. J., Alperi, A., Beaz-Hidalgo, R., Stackebrandt, E., Brambilla, E., Monera, A. and Martinez-Murcia, A. J.
2011. Aeromonas rivuli sp. nov., isolated from the upstream region of a karst water rivulet. International Journal of Systematic Evolutionary Microbiology. 61: 242-248.

Gopalakrishnan, V. 1961. Observation on infectious dropsy of Indian carps and its experimental induction. Journal of Scientific and Industrial Research. 20: 357-358.

Hatha, M., Vivekanandhan, A. A. and Joice, G. J. 2005. Antibiotic resistance pattern of motile aeromonads from farm raised fresh water fish. Christol International Journal of Food Microbiology. 98(2): 131-4.

Holt, J. G., Krieg, N. R., Sneath, P. H. A., Staley, J. T. and Williams, S, T. 1994. Bergeys Manual of Determinative Bacteriology, 9th edn., Williams \& Wilkins, Baltimore, Maryland, USA, pp 175-190.

Iqbal, M. M. 1995. Bacteriological studies on farmed mrigal, Cirrhinus mrigala. M. Sc. Thesis. Department of Fisheries Biology and Limnology, BAU, Mymensingh, pp 161.

Jagoda, de. S., Wijewardana, T. G., Arulkanthan, A., Igarashi, Y., Tan, E., Kinoshita, S., Watabe, S. and Asakawa, S. (2014). Characterization and antimicrobial susceptibility of motile aeromonads isolated from freshwater ornamental fish showing signs of septicaemia. Diseases of aquatic organisms. 109: 127-137.

Karunasagar, I., Ali, P. K. M., Jeyasekaran, G. and Karunasagar, I. 1986. Ulcerative form of Aeromonas hydrophila infection of Catla catla. Current Science. 55: 1194-1195.

Karunasagar, I., Rosalind, G. M., Karunasagar, I. and Rao, K. G. 1989. Aeromonas hydrophila septicemia of Indian major carps in some commercial fish farms of West Godavari District, 
Andhra Pradesh. Current Science. 58: 1044-1045.

Karvonen, A., Hakalahti, T., Seppala, O. and Valtonen, E. T. 2005. Sustainable production of healthy fish tackling parasitic threats with knowledge on their ecology. University of Helsinki, Department of Forest Ecology, Publications 34.

Karvonen, A., Rintamaki, P., Jokela, J. and Valtonen, E. T. 2010. Increasing water temperature and disease risks in aquatic systems, climate change increases the risk of some, but not all, diseases. International Journal for Parasitology. 40: 1483-1488.

Kholil, M. I., Hossain., M. M. M., Neowajh, M. S., Islam, M. S. and Kabir, M. 2015. Comparative efficiency of some commercial antibiotics against Pseudomonas infection in fish. International Journal of Fundamental and Applied Sciences. 2(3): 114-117.

Kumar, M. P. and Ramulu, K. S. 2013. Percentage composition of various species of Aeromonas in different organs of Pangasius hypophthalmus in culture ponds of kaikaluru and mudinepalli mandals in Krishna districts of Andhra Pradesh. International Journal of Research in Fisheries and Aquaculture. 3(2): 30-33.

Lechevallier, M., Seidler, R. J. and Evans, T. M. 1980. Enumeration and characterization of standard plate count bacteria in chlorinated and raw water supplies. Applied and Environmental Microbiology. 40(5): 922 - 930.

Mastan, S. A. 2013. Pseudomonas septicemia in Labeo rohita (Ham.) and Cyprinus carpio (Linn.) in Andhra Pradeshnatural occurrence and artificial challenge. International Journal of Pharmacy and Pharmaceutical Sciences. 5(2): 564-568.
Minana-Galbis, D., Urbizu-Serrano, A., Farfan, M., Fuste, M. C. and Loren, J. G. 2009. Phylogenetic analysis and identification of Aeromonas species based on sequencing of the cpn60 universal target. International Journal of Systemic and Evolutionary Microbiology. 59: 1976-1983.

OIE 2013. Aquatic Animal Health Code. Sixteenth Edition, World Organisation for Animal Health, Paris, France, pp. 284.

Rashid, M. M., Hossain, M. S. and Ali, M. F. (2014). Isolation and identification of Aeromonas hydrophila from silver carp and its culture environment from Mymensingh region. Journal of Bangladesh Agricultural University. 11(2): 373-376.

Rehulka, J. 2002. Aeromonas causes severe skin lesions in Rainbow trout (Oncorhynchus mykiss): Clinical pathology, haematology and biochemistry. Acta Veterinaria Brunensis. 71: 351-360.

Richards, R. H. and Roberts, R. J. 1978. A Review of Some Bacteria Diseases in Africa Culture Fisheries. Asian Journal of Medical Sciences. 3(5): 206-217.

Sabur, M. A. 2006. Studies on the ecology of the pathogenic bacteria Aeromonas hydrophila in indegenous and exotic carps under polyculture condition. Ph.D. Dissertation, Department of Aquaculture, Bangladesh Agricultural University, Mymensingh, Bangladesh.

Sarkar, M. J. A. and Rashid, M. M. 2012. Pathogenicity of the bacterial isolate Aeromonas hydrophila to catfishes, carps and perch. Journal of Bangladesh Agricultural University. 10(1): 157161.

Shewan, J. M., Hobbs, G. and Hodgkins, W. 1960. A determinative scheme for the identification of certain genera of gram negative bacteria with special reference 
to the Pseudomonaceae. Journal of Applied Bacteriology. 23: 379.

Soto- Rodriguez, S. A., Cabanillas-Ramos, J., Alcaraz, U., Gomez-Gil, B. and Romalde, J. L. 2013. Identification and virulence of Aeromonas dhakensis, Pseudomonas mosselii and Microbacterium paraoxydans isolated from Nile tilapia, Oreochromis niloticus, cultivated in Mexico. Journal of Applied microbiology. 115(3): 654662.

Tam, B., Gough, W. A. and Tsuji, L. 2011. The impact of warming on the appearance of Furunculosis in fish of the James Bay region, Quebec, Canada. Regional Environmental Change. 11: 123-132.

Taylor, P. W. 2003. Multiple antimicrobial resistance in chronic bacterial infection of koi carp. North American Journal of Aquaculture. 65(2): 120-125.

Triyanto, A. and Wakabayashi, H. 1999. Genotypic diversity of strains of Flavobacterium columnare from diseased fishes. Fish Pathology. 34: 6571.

Yi, S. W., You, M. J., Lrr, H. B. and Shin, G. W. 2012. A case of Aeromonas veronii infection in Israeli carp (Cyprinus carpio): phylogenetic analysis and antimicrobial resistance. Korean Journal of Publishing Service. 35: 239243.

Zheng, W., Cao, H. and Yang, X. 2012. Grass carp (Ctenopharyngodon idellus) infected with multiple strains of Aeromonas hydrophila. African Journal of Microbiology Research. 6(21): 45124520.

\section{How to cite this article:}

Koel Bhattacharya Sanyal, Debapriyo Mukherjee, Ananya Guchhait and Gadadhar Dash. 2018. Phenotypic and Molecular Identification of Bacterial Species in Indian Major Carps and Exotic Carps from South 24 Parganas, West Bengal, India. Int.J.Curr.Microbiol.App.Sci. 7(01): 534547. doi: https://doi.org/10.20546/ijcmas.2018.701.064 